\title{
Agro-Industrial Residues Utilization for Surfactin Production: Cassava Wastewater
}

\author{
Cristiano José de Andrade*, Aline Wasem Zanotto, Lidiane Maria de Andrade, Gláucia Maria Pastore \\ and Claudio Augusto Oller do Nasciment
}

Department of Chemical Engineering, University of São Paulo, Brazil

Received: February 02, 2018; Published: March 28, 2018

*Corresponding author: Cristiano José de Andrade, Department of Chemical Engineering, Polytechnic School, University of São Paulo, São Paulo, Brazil, Avenue Escola Politécnica, Zip Code: 05350-000, Tel: +55 19 981-543393; Email: eng.crisja@gmail.com

\section{Opinion}

Biosurfactants are amphiphilic compounds produced, essentially, by microbial cells. The production/applications of biosurfactants are aligned to the green chemistry concept, which includes antimicrobial (bacteria, fungal, mycoplasma, etc), microbial enhanced oil recovery (MEOR), and emulsification, among others [1]. Surfactin, one of the most well-know biosurfactants, was first found in 1968 by Arima, Kakinuma e Tamura [2]. Currently, there are a few surfactin manufacturers as Lipofabrik and Sigma Aldrich that use mineral salt media for surfactin production. Regarding surfactin production, the culture medium represents $\approx 30 \%$ total production cost. Thus, some agro-industrial residues have been investigated as alternative culture medium such as olive mill waste, brewery wastewaters, sugarcane and beet molasses, whey, cassava wastewater, etc [3]. In this sense, the cassava processing industry generates $\approx 300$ liters of cassava wastewater/ton of cassava, residue which currently has not industrial application. Cassava wastewater contains high minerals (potassium, calcium, magnesium, etc), carbon and nitrogen concentrations, which allow a good microbial growth: bacteria, fungi and yeasts.

Nevertheless, cassava wastewater has, inherently, cyanide potentially hazardous to the environment. The surfactin production using cassava wastewater was already reported at different bioreactor volumes: $250 \mathrm{~mL}, 7.5$ liters and 80 liters. However only Andrade et al. [1] investigated the surfactin purification (ultrafiltration), which was produced using cassava wastewater, the authors concluded that when compared to mineral salt medium, the use of agro-industrial residues as culture medium makes the surfactin purification more complicated, since an extra source of protein is added to the system-the culture medium itself. Therefore, the use of agro-industrial residues as alternative culture medium for surfactin production is an interesting strategy due to the costs reduction itself and also to make the process even more environmentally friendly. However, the alternative culture medium has to provide all nutrients to make feasible the surfactin production during the bioprocess and preferably has no or low protein concentration for surfactin ultrafiltration.

\section{Conclusion}

Despite the use of agro-industrial residues as culture medium in biotechnological processes (surfactin production) be a quite interesting approach, since it reduces production costs and make the process even more environmentally friendly; some concerns need to be taken into account, for instance the protein concentration. In this sense, the residue pretreatment step(s) such as protein removal could make the use of alternative culture medium infeasible (economically).

\section{References}

1. Andrade CJ, Barros FFC, Andrade LM, Rocco SA, Sforça ML, et al. (2016) Ultrafiltration based purification strategies for surfactin produced by Bacillus subtilis LB5a using cassava wastewater as substrate. J Chem Technol Biotechnol 91(12): 3018-3027.

2. Arima K, Kakinuma A, Tamura G (1968) Surfactin, a crystalline peptidelipid surfactant produced by Bacillus subtilis: isolation, characterization and its inhibition of fibrin clot formation. Biochem Bioph Res Co 31(3): 488-494.

3. Andrade CJ, Andrade LM, Rocco SA, Sforça ML, Pastore GM, et al. (2017) A novel approach for the production and purification of mannosylerylthritol lipids (MEL) by Pseudozyma tsukubaensis using cassava wastewater as substrate. Sep Purif Technol 180: 157-167. 


\section{(C) (i) This work is licensed under Creative} Submission Link: https://biomedres.us/submit-manuscript.php

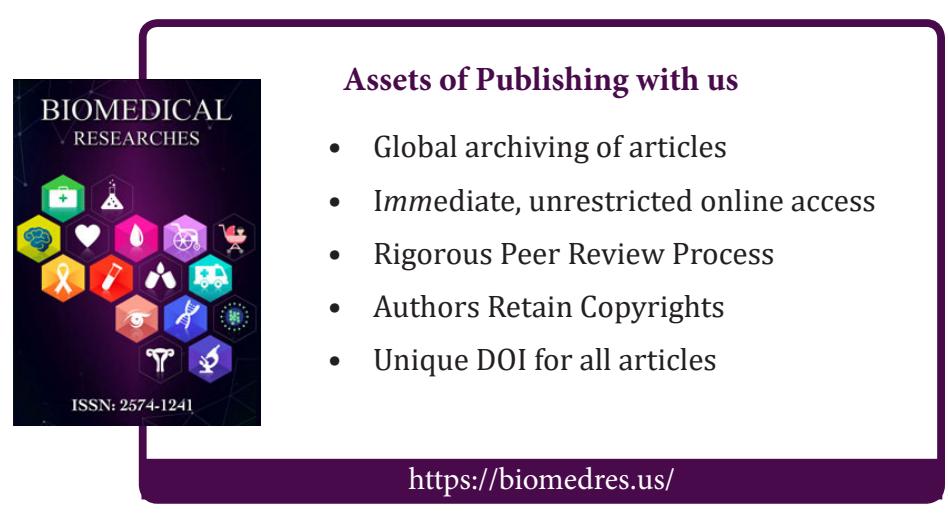

